Meta

Journal des traducteurs

Translators' Journal

\title{
Existential Sentences in Arabic-English Translation
}

\section{Yowell Y. Aziz}

Volume 40, numéro 1, mars 1995

URI : https://id.erudit.org/iderudit/001930ar

DOI : https://doi.org/10.7202/001930ar

Aller au sommaire du numéro

\section{Éditeur(s)}

Les Presses de l'Université de Montréal

\section{ISSN}

0026-0452 (imprimé)

1492-1421 (numérique)

Découvrir la revue

Citer cet article

Aziz, Y. Y. (1995). Existential Sentences in Arabic-English Translation. Meta, 40(1), 47-53. https://doi.org/10.7202/001930ar

\section{Résumé de l'article}

L'auteur propose une étude des phrases "existentielles" dans la traduction arabe-anglais à partir d'un corpus d'observation des deux langues (un livre écrit en arabe et traduit en anglais : Awlaadu Haarratma). Il releve les phrases existentielles dans chacune des versions et constate que ces dernières, en arabe, ont été traduites par des phrases anglaises du même type, mais que les phrases existentielles anglaises sont quelquefois des traductions de phrases arabes non existentielles. Il conclut que les phrases anglaises ont deux fonctions : affirmer l'existence d'une situation, et amener une situation donnée à l'existence, les phrases arabes n'ayant que la première de ces fonctions. De plus, l'anglais fait un usage plus important de phrases existentielles et les deux langues différent dans leur vision du monde, une situation étant souvent envisagée par l'anglais comme un état, alors que pour l'arabe, elle est un événement. 


\title{
EXISTENTIAL SENTENCES IN ARABIC-ENGLISH TRANSLATION
}

\author{
YOWELL Y. AZIZ \\ Mosul Universin, Mosul. Irag
}

\begin{abstract}
Résumé
L'auteur propose une éfude des phrases rexistentielles" dans la traduction arabeanglais a parrir d'un corpus d'observation des deur langues (un livre écrit en arabe ef traduit en anglais: Awlaadu Haarratinal. Il releve les phrases existentielles dans chacune des versions et constate que ces dernières. en arabe, ont été fraduites par des phrases anglaises du même type. mais que les phrases existentielles anglaises sont quelquefois des traductions de phrases arabes non existentielles. Il conclut que les phrases anglaises ont deux fonctions: affirmer l'existence d'une situation, et amener une sifuation donne à l'existence. les phrases arabes $n$ 'ajant que la première de ces fonctions. De plas. I'anglais fait un usage plus important de phrases existentielles ef les deux langues different dans leur vision du monde, une simation étant souvent envisagée par l'anglais comme un état, alors que pour l'arabe, elle est un événement.
\end{abstract}

\section{INTRODUCTION}

Existential sentences assert either the absolute existence of an entity, e.g. There is God, or the existence of an entity in a particular location, e.g. There is a ghost in the garden. They have certain syntactic and semantic features which are believed to be common to most if not all languages. Syntactically, their structure consists of an indefinite nominal expression and a locative, explicitly expressed or implied. In some languages they are introduced by an unstressed semantically empty word to avoid starting a sentence with an indefinite expression: English there. Hebrew yes.. Other languages use a special word order placing the locative before the indefinite expression: Arabic, fi al-hadiiqati rajulun (in the garden a man: There is a man in the garden). Semantically, they are said to refer to the existence of something or they introduce something into the world of discourse (Lyons 1967: Bolinger 1977).

This paper examines existential sentences in Arabic-English translation. We will first discuss breifly the main types of existential constructions in the two languages, then investigate these constructions in an Arabic text and its English translation. We will also attempt to find out how existentials are equated across the two languages and what similarities and differences are involved in the process of translation. The data are based on a corpus comprising 552 pages of an Arabic novel. Awlaadu Haarratina, by Najib Mahfuz (Beirut, Sth edition, 1986) and its English translation by Philip Stewart (London, Heinemann. 1981).

English existential sentences have been discussed by a number of scholars including Quirk et al. (1985: 1402-1414), who make use of the idea of "given" and "new" information in their description. English uses the existential "there" to avoid stanting an utterance with a theme conveying new information. Thus instead of $A$ ghost is in the garden the speaker produces There is a ghost in the garden. The sentence with an indefinite theme is felt to be awkward (Quirk 1985: 1402).

The commonest type of existentials in English is the one which comprises "there + be." Occasionally, a verb other than be is used in this construction. There is also a minor 
type of existentials which contain "have" instead of "there," $e . g$. I have three stamps missing from my collection ( $c$. There are three stamps missing from my collection). In this paper, We will deal exclusively with "there" existentials.

Briefly, existential sentences in English may be grouped under four headings.

a. Locative existentials. which assert the existence of an entity in a certain location. These sentences have the structure: There + be + predication, and can be directly related to the basic patterns of English sentences.

1. Nothing is left here - There is nothing left here.

2. In the next room a man is giving a lecture - In the next room. there is a man giving a lecture.

b. Bare existentials, which assert the absolute existence of a person or a thing. They have the structure: there + be + nominal expression.

3. There is no justice.

These sentences are not directly derived from the basic patterns. Often they are accounted for on the basis of deletion, c.g. There is no justice in this place. This construction also includes the patterns where the indefinite expression is modified by a relative clause or by an infinitive.

4. There are plenty of people who would like to do it.

5 . There is no need to stay.

c. Existentials with a verb other than be, which bring into existence some entity. Instead of verb be, they contain certain verbs termed verbs of appearance - or coming into existence - on the scene (Firbas 1966: 243: Breivik 1981).

6. There appeared some clouds in the horizon.

d. Existentials with a definite expression, which have the structure: There + be + definite expression. These definite existentials are also termed list sentences (Rando and Napoli 1978).

7. - How could we get there? - Well, there's the trolley (Rando and Napoli 1978).

There is no systematic study (as far as I know) which is wholly concerned with describing existential sentences in modern Standard Arabic. The little information that one obtains about these sentences is scattered in traditional grammar books. I will therefore attempt a brief description of Arabic existential sentences here.

Four type of existential constructions may be recognized in Arabic.

a. Existential sentences exploiting word order. Arab grammarians stress that in Standard Arabic a sentence cannot start with an indefinite expression (which is termed subject). Thus, *rajulun fi al-hadiiqati (a man in the garden: a man is in the garden) is unacceptable. In such cases, the normal word order, subject-predicate, is inverted: fi al-hadiiqari rajulun (in the garden a man: There is a man in the garden), which is described as predicate-subject. This reorganization of the elements of a sentence confirms the general syntactic restriction on existential sentences with regard to an indefinite element in the initial position. However, in a negative or an interrogative construction where the initial position is occupied by the negative or interrogative particle, the original subject-predicate order is permitted: la rajula fi al-hadiiqati (Neg-particle man in the garden: There is no 
man in the garden); hal rajulun fi al-hadiiqati? (Q-particle man in the garden: Is there a man in the garden?). In this pattern Arabic exploits the relative flexibility of its word order to reorganize the message thematizing "given" information and placing "new" information towards the end of the sentence.

b. Thamma Existentials. The word thamma (f. thammata) is used in the initial position of this construction to avoid starting a sentence with an indefinite expression conveying "new" information. Thamma is in this pattern semantically empty and often introduces absolute existentials, as in:

7. Thamma asbaabun okhra. (thamma-reasons other: There are other reasons.)

In negative or interrogative sentences and in sentences marked for past time by the existential verb kaana, thamma follows the negative and the interrogative particles and kaana.

8. Iam yakun thamma sababun li dhaalika. (neg-particle kaana thamma reason for that: There was no reason for that.)

9. a thamma shai' un yaqifu fi tariiqika? (Q-particle thamma something standing in your way: Is there something standing in your way?)

c. Hunaaka (Hunaalika) Existentials. In this type hunaaka (or hunaalika) is used initially as a dummy form followed by an indefinite expression and a locative.

10. hunaaka rajulun fi al-hadiiquti. (hunaaka man in the garden: There is a man in the garden.)

In the grammar of Standard Arabic, hunaaka is an adverb of place (similar to the adverbial "there" in English). The dummy hunaaka was introduced at the beginning of this century, by translators, under the influence of European languages, much to the chagrin of the purists, who have been fighting a losing battle against this use of hunaaka. In this sense, hunacka has taken some of the function of word order ( $f$. the example, fi al-hadiiqati rajulun, in a above).

d. Existentials with a verbal element. Normally, existential sentences in Arabic are verbless, at least at the level of surface structure. They are therefore timeless. If the speaker wants to mark these sentences for time, especially the past, the verb kaana is used. There is however a type of existentials which have the verb yujadu "exist." In such sentences "existence" is explicitly expressed.

11. yujadu rajulun fi al-hadiigati. (exist a man in the garden: There is a man in the garden.)

These sentences follow the normal Arabic pattem, VSA.

\section{ANALYSIS OF THE TEXTS}

The Arabic text and its English translation were examined with regard to the existential constructions discussed in the Introduction. The results will be stated briefly in this section; the next section will be devoted to explaining the results, and then we will summarize the main conclusions.

The Arabic text revealed 120 instances of existential sentences, distributed as follows: the word order construction 76 instances, existentials with the verb yujadu 21 instances, thamma existentials 15 instances, and hunaaka existentials 8 instances.

In the English text, 270 instances of existentials were attested; 141 instances belong to bare existential construction. Within this type the relative pattem claims 14 instances, the infinitive 9 and the rest belong to the normal bare existential pattern ( $c f$. example 3 ). 
The next most frequent subtype was the locative existential, where 111 instances were attested. The definite existential and existentials with a verb other than be have each 9 instances. Tables 1 and 2 summarize these results.

TABLE I

Types of existentials in the English text

\begin{tabular}{|lcc|}
\hline Type & $\mathbf{N}^{\circ}$ of instances & $\%$ \\
\hline Bare & 141 & 52.22 \\
\hline Locative & 111 & 41.12 \\
\hline Definite & 9 & 3.33 \\
\hline Verb other than be & 9 & 3.33 \\
\hline Total & 270 & 100 \\
\hline
\end{tabular}

TABLE 2

Types of existentials in the Arabic text

\begin{tabular}{|lcc|}
\hline Type & No $^{\circ}$ of instances & $\%$ \\
\hline Word order & 76 & 63.33 \\
\hline Yujadu & 21 & 17.50 \\
\hline Thamma & 15 & 12.50 \\
\hline Hunaaka & 8 & 6.67 \\
\hline Total & 120 & $1(K)$ \\
\hline
\end{tabular}

\section{EXPLANATION OF THE RESULTS}

Two main points will be discussed in this section: correspondence and noncorrespondence between the instances of existentials in the two texts. First we will be concerned with Arabic non-existential sentences 1 's. English existentials; then we will deal with correspondence between the Arabic existentials and the English existentials.

\section{Arabic Non-existential Sentences vs. English Existentials}

A notable fact emerging from the analysis of the two texts is that Arabic uses fewer existential constructions than English does: 120 instances is 270 (44.44\%). All the four types of English existentials have corresponding instances from among instances of nonexistential sentences in the Arabic text as illustrated by these examples. (The number between brackets refers to the page.) 
12. There was silence ( 52$)$. (Bare existential) na saada al-samiu (83).

13. There was light behind the shutter (55). (Locative) w'a taraa'l li 'aynayhi anw'darun waraa' a shiishi ha'd al-naw'aafidhi (87).

14. There followed a flurry movement (85). (Verb other than he) w'a tatuaba' at harakaatun khaatifatun (132).

15. ... and there was Idris's voice saying... (38) (Definite) wa idhaa bi sawti idriis yaquulu... (61).

By far the largest number of instances of non-correspondence belongs to bare existentials, although the highest percentage is found in the existential construction which has a verb other than be; 8 instances out of the total 9 have no corresponding Arabic existentials. Only 1 instance has an Arabic existential equivalent represented by hunaaka construction.

16. There does not seem to be any reason to be frightened (189). vabdu an laa daci iya hunaaka li al-khawfi (292).

The next highest percentage is found in the definite existential, where 7 out of the total 9 instances have no existential equivalents in Arabic. The 2 instances that have are realized by word order and hunaaka constructions.

17. There is the book, the greatest book of magic (312). hunaaka al-kiraahu, kitaahu al-sihri al-an'w'alu (216).

18. But there was also the Trustee (1.39). wa laakinna fiiha avdan naazira al-naqfi (216).

The definite English existential frequently corresponds to a certain construction in Arabic introduced by idhaa expressing "suddenness." This construction is normally used when some entity comes into the world of discourse (presentative existence) as in examples 15 and 19.

19. There was Omayma looking very pretly (18).

wa idha hi omayma talhaqu hi hi (31).

The high percentage of non-correspondence between existential sentences in the two texts (English 270 vs. Arabic 120 instances) may be explained on the basis of how the two languages envisage a certain situation'. The English existential sentence introduced by "there+be" depicts a situation as a state, something which has already happened and is going on. Thus. There was silence basically means Silence had started some rime before and w'as going on at the time of utterance. In this example the situation expressed by the sentence is bare existential; but this explanation also holds for a locative existential: There is a man in the room roughly means a man came in and is now' in the room. In each of these cases the reference is to the situation following the event. This may be contrasted with the other type of English existentials which has a verb other than be. E.g. There came a man. Such sentences refer to the event itself rather than to the state following it (cf. Quirk 1985: 1408). Arabic, on the other hand, often envisages such a situation as dynamic: it refers to the event, or its coming into existence. To express this, it chooses a semantically full verb rather than an empty stative verb like the English be. The following examples from the corpus illustrate the point.

20a. There was silence (52).

b. wa saada samtum (83). (Lit. Silence prevailed.)

21 a. There was no shortage of solutions (78).

b. Lam ladiq binaa al-huluulu (122). (Lit. Solutions came to us in no small number.)

22a. There was anger in his voice (57).

b. Washa saw'ruhu bi al-ghadabi (59). (Lit. His voice revealed anger.) 
23a. There is pain in your face (64).

b. w'ajhuka yundhiru bi al-shaqaa i $(100)$ ). (Lit. Your face shows misery.)

24a. There was a great deal of laughing and shouting (141).

b. w'a ta' aalat dahikatun wa sarkatum (218). (Lit. Laughing and shouting rose.)

2.5a. There was a knock at the door (170)).

b. wa duqqa al-haahu (264). (Lit. The door was knocked.)

26a. There were looks of protest (179).

b. laahat nazaraatu al-inkadri (278). (Lit. Looks of protest appeared.)

27 a. There was silence in the cafe $(208)$.

b. H'a saada al-sammu fi al-qahn'ari (322) (Lit. Silence prevailed in the coffee.)

In each of these examples, the reference in English is to a situation perceived as a state. This is true even of example 25 a. containing the verb "knock," which expresses a short action. Here it is envisaged, so to speak, as a "frozen" situation, a situation going on, albeit for a short period. In Arabic, the situations expressed by these examples are perceived as dynamic, occurring rather than existing. Such situations are expressed by non-existential sentences containing full lexical verbs.

Further evidence in support of this point is the high percentage of English existential sentences with a verb other than be cquated with non-existential constructions in Arabic. These English sentences basically describe dynamic situations, which in Arabic are normally expressed by non-existential constructions.

\section{Arabic Existentials vs. English Existentials}

Correspondence between Arabic existentials and English existentials in the two texts is, as stated before. lower than $50 \%$. However, it is found between all the patterns of the two languages, as shown by these examples.

28a. There is no room in the house (35). (l.ocative)

b. fa la makaana fi al-hayfi at-kahiiri (56). (Word order) (Lit. no place in the big house.)

29a. There's no drudgery (38). (Bare)

b. Ia camala li al-quuti (61). (Word order) (Lit. no work for food.)

30). There was a general trade (7.3). (Bare)

b. thammata tijararatun mushtarakutun (115). (Thamma) (Lit. thammata general trade.)

$31 \mathrm{a}$. Is there any way to escape? (98) (Bare inlinitive)

b. 'a la yujadu sabiilun ila al-harahi (1.52) (Yujadu) (Lit. Q-particle Neg--particle yujadu way to escape?)

32a. There are men in the gebel. (259). (Locative)

b. fa humaaka fi al-jabali rijaalun (40I). (Hunaaka) (Lit. Hunaaka in the mountain men.)

33a. There is the book, the greatest book of magic (312). (Definite)

b. hunaaka al-kitaabu - kiloahu al-sihri al-an'w'alu (486). (Hunaaka) (Lit. hunaaka the book. the grealest book of magic.)

Arabic existential sentences are usually verbless ( $f f$ examples $28-30$ and $32-33$ ). In isolation. such sentences are timeless; in speech, they acquire their time from the context. Occasionally, they are marked for time, especially the past. In this case, kaana is used often in the first type (word order), but also in the other types.

34. kaana fi al-dunva khavrun (32).

(Lit. kaana in the world good: There was some good in the world (118).)

35. wa kaana thammata mas yadulla 'ala mastidin (15.3).

(Lit. and kaana thammata what points to a saint's day celebration: There were signs that a saint's day was being celebrated (98).)

This kaana. termed by Arab grammarians al-naaqisatu "defective." functions as a logical copula linking the subject of the sentence with the predicate. There is another type 
of kaana, termed al-taamatu "the full verb," which is followed by a nominal expression in the nominative, as in the first instance of kaana in the following example: kaana rajulun wa kanaa lahu banuunun (Wright 1971: II, 99). This latter type, which expresses bare existence and "encapsulates" its subject, is now felt to be archaic. No instances of it were attested.

In example $3 \mathrm{lb}$. the existential nature of the utterance is explicitly expressed by the verb yujadu "exist." Here is another example of the same type.

36. yujadu rajulun fi suuqi al-muqattami jaawaza al-mi' ata wa al-khamsiina min al-'umri (484). (There's a man over hundred and fifty in Souk Mukattam (309).)

Both kaana and yujadu are stative verbs; they refer to a situation going on, a state.

If we turn to the corresponding English existentials, we find that they all have the structure "There + be," which refers to the existence of a situation rather than to its coming into existence. They describe the same sort of situation which is described by the corresponding Arabic existential sentences.

\section{CONCLUSION}

Existential sentences are said to have two semantic functions: (i) they assert the existence of a situation and (ii) they bring into existence a situation ( $c f$. Lyons 1967; Bolinger 1977: Breivik 1981; Ziv 1982). English existentials seem to have both functions, as shown above; whereas Arabic existential sentences have only function (i), they refer to the existence of a situation. Function (ii) of existentials, bringing a situation into existence, is normally expressed in Arabic by non-existential constructions.

On the quantitative level, English makes more use of existential sentences than Arabic does. This partly follows from the semantic function of existentials in the two languages. Apart from this, the two languages differ in the way they perceive a situation; English often envisages it as a state, whereas Arabic views it as an event.

The implication of these findings for translation is obvious; some readjustment has to be made where existential sentences are involved.

\section{Notes}

1. The term situation is used here in the sense used by Lyons (1977: 494) as a cover-all term which includes states, events, activities, etc.

\section{REFERENCES}

BOLINGER. Dwight (1977): Meaning and Form, London, Longman

BREIVIK, Leiv Egil (1981): "On the Interpretation of Existential There", Language, 57, pp. 1-25

FIRBAS, Jan (1966): "Nonthematic Subjects in Contemporary English". Travaux linxuistiques de Praque, 2, pp. 239.256.

LYONS, John (1967): "A Note on Possessive, Existential and Locative Sentences". Foundation of Language. 3. pp. $390-396$.

LYONS, John (1977): Semanrics, 2 vols. Cambridge. The University Press.

QUIRK, Randolph, GREENBAUM, Sidncy, LEECH, Geoffrey and Jan SVARTVIK (1985): A Comprehensive Grammar of the English Language. London, Longman.

RANDO, Emily and Donna Jo NAPOL.I (1978): "Definiteness in There-sentences", Language, 54, pp. 300)-31.3. WRIGHT, William (1971): A Grammar of the Arabic Language. Cambridge. The University Press.

ZIV, Yael (1982): "On So-called Existentials: A Typological Problem". Lingua, 56. pp. 261.281. 